\title{
KONSEP MANAJEMEN SUMBER DAYA MANUSIA DAN PRAKTIKNYA DI LEMBAGA PENDIDIKAN
}

\author{
SYAWAL KURNIA PUTRA', RESKI MEI ${ }^{2}$ \\ 1,2Pascasarjana Universitas Islam Negeri Alauddin Makassar, Indonesia \\ Email: ${ }^{1}$ syawalp1@gmail.com, ${ }^{2}$ meyrezky2@gmail.com
}

\section{Abstract: The Concept of Human Resource Management and Its Practice in Educational Institutions}

Human resources (HR) have a significant role in every activity in an institution, including educational institutions. Human resources (HR) must be managed or managed properly in accordance with their functions so that these human resources (HR) can play a role in accordance with their duties and functions in the institution they are involved in. Human resource management is a very important aspect in the general education process. Therefore, the functions in the management of human resources must be carried out optimally so that the needs concerning individual, organizational/institutional, organizational or institutional goals can be achieved. In addition, with good human resource management procedures, it is hoped that the shortcomings and problems faced by the Indonesian people, namely those related to competitiveness, can be overcome. This paper discusses Human Resource Management associated with Education in Schools, using the literature review method to discuss the concept of $H R$ Management which is described in several ways. There are several main issues that will be discussed in this paper, namely: First, the definition of $H R$ Management, secondly the scope of HR Management in education in schools, and thirdly, the objectives of HR Management are related to education in schools. A search in various writings and journals concludes several things related to the concept of HR Management as follows, one of the fields of general management which includes aspects of planning, organizing, implementing, and controlling.

Keywords: Human Resource, Educational Institution, Human Resources Management

\section{Abstrak: Konsep Manajemen Sumber Daya Manusia dan Praktiknya di Lembaga Pendidikan}

Sumber daya manusia (SDM) memiliki peran yang signifikan dalam setiap kegiatan pada suatu lembaga termasuk lembaga pendidikan. Sumber daya manusia (SDM) harus dapat dikelola atau di-manage dengan baik sesuai dengan fungsinya supaya sumber daya manusia (SDM) ini dapat berperan sesuai dengan tugas dan fungsinya pada lembaga yang digelutinya. Pengelolaan sumber daya manusia merupakan aspek yang sangat penting dalam proses pendidikan secara umum. Oleh karena itu, fungsi-fungsi dalam pengelolaan sumber daya manusia harus dilaksanakan secara optimal sehingga kebutuhan yang menyangkut tujuan individu, organisasi/lembaga, organisasi ataupun kelembagaan dapat tercapai. Di samping itu, prosedur pengelolaan sumber daya 
manusia yang baik diharapkan kekurangan dan problem yang dihadapi oleh bangsa Indonesia, yaitu terkait dengan kemampuan daya saing dapat teratasi. Tulisan ini membahas tentang Manajemen Sumber Daya Manusia dikaitkan dengan Pendidikan di Sekolah, dengan menggunakan metode kajian pustaka pembahasan mengenai konsep Manajemen SDM yang dideskripsikan pada beberapa hal. Adapun beberapa pokok permasalahan yang akan dibahas dalam penulisan ini yakni: Pertama definisi Manajemen SDM, kedua ruang lingkup Manajemen SDM pada pendidikan di Sekolah, dan yang ketiga tujuan Manajemen SDM dikaitkan pada pendidikan di Sekolah. Penelusuran di berbagai tulisan dan jurnal menyimpulkan beberapa hal berkaitan dengan konsep Manajemen SDM tersebut sebagai berikut salah satu bidang dari manajemen umum yang meliputi segi-segi perencanaan, pengorganisasian, pelaksanaan, dan pengendalian.

Kata Kunci: Sumber Daya Manusia, Lembaga Pendidikan, Manajemen Sumber Daya Manusia

\section{PENDAHULUAN}

Setiap organisasi pada umumnya sangat memerlukan adanya sumber daya manusia karena bagi organisasi, sumber daya manusia merupakan asset paling berharga yang dimilikinya. Sumber daya manusia merupakan pekerja, pegawai, karyawan, atau orang-orang yang mengerjakan atau mempunyai pekerjaan (Ulfatin \& Triwiyanto, 2016; Akilah \& Rahman, 2020). Manusia merupakan sumber daya yang paling penting dalam usaha suatu organisasi untuk mencapai keberhasilan sumber daya manusia menunjang organisasi dengan bakat, karya, dorongan/motivasi, kreativitas dan juga inovasi. Meskipun aspek teknologi dan aspek-aspek lainnya telah sempurna dalam organisasi tersebut, tapi sulit mencapai tujuan-tujuan yang telah ditetapkan sebelumnya. Unsur manusia tetap sangat penting dan dibutuhkan (Hasibuan, 2017).

Suatu lembaga pasti akan menghadapi berbagai permasalahan sumber daya manusia yang kompleks, maka dari itu diperlukan adanya pengelolaan mengenai manajemen sumber daya manusia. Dalam implementasinya manajemen sumber daya manusia melakukan kegiatan yang dapat mendukung tercapainya tujuan dari suatu lembaga/instansi (Yunanik, 2013).

\section{PEMBAHASAN}

\section{Manajemen Sumber Daya Manusia}

Manajemen Sumber Daya Manusia (SDM) dalam bahasa Inggris disebut "Human Resource management" yang di singkat menjadi HRM (Arsyad, 2011). Manusia merupakan bagian dari sumber daya yang dibutuhkan oleh perusahaan/organisasi. Namun, kebijakan manajemen masih banyak yang belum 
memperhatikan pentingnya peran sumber daya manusia (SDM) (Herfan, 1999). Jadi dari pengertian tersebut dapat saya analisa bahwa perusahaan kebijakan masih belum memerhatikan kepentingan sumber daya manusia.

Pengelolaan sumber daya manusia merupakan aspek yang sangat penting dalam proses pendidikan secara umum. Oleh karena itu, fungsi-fungsi dalam pengelolaan sumber daya manusia harus dilaksanakan secara optimal sehingga kebutuhan yang menyangkut tujuan individu, organisasi/lembaga, organisasi ataupun kelembagaan dapat tercapai. Di samping itu, prosedur pengelolaan sumber daya manusia yang baik diharapkan kekurangan dan problem yang dihadapi oleh bangsa Indonesia, yaitu terkait dengan kemampuan daya saing dapat teratasi.

Beberapa pandangan para ahli mengenai konsep manajemen personalia, seperti Edwin B. Flippo menyatakan bahwa manajemen personalia merupakan proses perencanaan, pengorganisasian, pengarahan dan pengendalian dari pengadaan tenaga kerja, pengembangan, kompensasi, integrasi, pemeliharaan dan pemutusan hubungan kerja dengan maksud untuk mencapai tujuan atau sasaran perorangan, organisasi, dan masyarakat (Amirullah \& Budiyono, 2004). Lain halnya yang diungkapkan Andrew F Sikula, menyatakan bahwa administrasi kepegawaian adalah penempatan orang-orang ke dalam suatu organisasi/lembaga. Implementasi tenaga kerja manusia adalah pengadaan, pemeliharaan, penempatan, indoktrinasi, latihan dan pendidikan sumber daya manusia. Sedangkan menurut John B. Miner dan Mary Green Miner, menyatakan bahwa manajemen personalia didefinisikan sebagai suatu proses pengembangan, menerapkan, dan menilai kebijakan-kebijakan, prosedur-prosedur, metodemetode, dan program- program yang berhubungan dengan individu pegawai dalam organisasi (Hasibuan, 2017).

Manajemen sumber daya manusia bisa didefinisikan sebagai proses serta upaya untuk mengembangkan, memotivasi, serta mengevaluasi keseluruhan sumber daya manusia yang diperlukan perusahaan dalam pencapaian tujuannya. Pengertian ini mencakup dari mulai memilih siapa saja yang memiliki kualifikasi dan pantas untuk menempati posisi dalam suatu organisasi the right man on the right place seperti yang disyaratkan pada suatu lembaga atau organisasi hingga bagaimana agar kualifikasi ini dapat dipertahankan bahkan ditingkatkan serta dikembangkan dari waktu ke waktu. Oleh karena itu, manajemen sumber daya manusia merupakan proses yang berkelanjutan, sejalan dengan proses pendidikan itu, maka perhatian terhadap sumber daya manusia ini dapat memiliki tempat yang khusus dalam organisasi pendidikan.

Pada dasarnya, fungsi bagian personalia adalah merencanakan konsep perekrutan, pengembangan dan peningkatan kualitas sumber daya manusia yang 
diperlukan oleh perusahaan. Kebijakan- kebijakan yang menyangkut peraturan tenaga kerja, kualifikasi perekrutan, pengembangan karier dari mulai pengiriman tenaga kerja untuk mengikuti pelatihan-pelatihan hingga melanjutkan studi, program insentif maupun bonus bagi tenaga kerja merupakan fungsi utama dari bagian personalia ini (Trisnawati, 2005).

Fungsi manajemen sumber daya manusia antara lain meliputi perencanaan, pengorganisasian, pengerahan, pengendalian, pengadaan, pengembangan, kompensasi, pengintegrasian, pemeliharaan, kedisiplinan, dan pemberhentian.

1. Perencanaan (planning) adalah suatu proses tahap awal dalam sebuah organisasi yang berkaitan dengan kebutuhan perusahaan dalam membantu terwujudnya tujuan.

2. Pengorganisasian (organizing) adalah kegiatan untuk mengorganisasikan semua karyawan dengan menetapkan pembagian kerja, hubungan kerja untuk mencapai tujuan.

3. Pengarahan (directing) adalah kegiatan mengarahkan semua karyawan, agar mau bekerja sama dan bekerja efektif serta efisien dalam membantu tercapainya tujuan perusahaan, karyawan, dan masyarakat.

4. Pengendalian (controlling) adalah kegiatan mengendalikan semua karyawan, agar menaati peraturan-peraturan perusahaan dan bekerja sesuai dengan rencana.

5. Pengadaan (procurement) adalah proses penarikan, seleksi, penempatan, orientasi, dan induksi untuk mendapatkan karyawan yang sesuai dengan kebutuhan perusahaan.

6. Pengembangan (development) adalah proses peningkatan keterampilan teknis, konseptual, dan moral karyawan melalui pendidikan dan pelatihan. Pendidikan dan pelatihan yang diberikan harus sesuai dengan kebutuhan pekerjaan masa kini maupun masa depan.

7. Kompensasi (compensation) adalah pemberian balas jasa langsung (direct) dan tidak langsung (indirect), uang atau barang kepada karyawan sebagai imbalan jasa yang diberikan kepada perusahaan.

8. Pengintergrasian (integration) adalah kegiatan untuk mempersatukan kepentingan perusahaan dan kebutuhan karyawan, agar tercipta kerja sama yang serasi dan saling menguntungkan.

9. Pemeliharaan (maintenance) adalah kegiatan untuk memelihara atau meningkatkan kondisi fisik, mental, dan loyalitas karyawan, agar mereka tetap mau bekerja sama sampai pensiun.

10. Kedisiplinan merupakan fungsi manajemen sumber daya manusia yang terpenting dan kunci terwujudnya tujuan karena tanpa disiplin yang baik sulit terwujud tujuan yang maksimal. 
11. Pemberhentian (separation) adalah putusnya hubungan kerja sesorang dari suatu perusahaan (Trisnawati, 2005, h. 67-68).

\section{Ruang Lingkup Pengelolaan Sumber Daya Manusia}

Manajemen sumber daya manusia (SDM) adalah bagian dari manajemen. Oleh karena itu, teori-teori manajemen umum menjadi dasar pembahasannya. MSDM lebih memfokuskan pembahasannya mengenai pengaturan peranan manusia dalam mewujudkan tujuan yang optimal. Pengaturan ini meliputi masalah perencanaan, pengorganisasian, pengarahan, pengendalian, pengadaan, pengembangan, kompensasi, pengintegrasian, pemeliharaan, kedisiplinan, dan pemberhentian tenaga kerja untuk membantu terwujudnya tujuan organisasi/lembaga, pegawai, dan masyarakat.

\section{Perencanaan Pegawai}

Perencanaan pegawai merupakan kegiatan untuk menentukan kebutuhan pegawai, baik secara kuantitatif maupun kualitatif untuk sekarang dan masa depan. Penyusunan rencana personalia yang baik dan tepat memerlukan informasi yang lengkap dan jelas tentang pekerjaan atau tugas yang harus dilakukan dalam organisasi. Karena itu, sebelum menyusun rencana, dilakukan analisis pekerjaan dan analisis jabatan untuk memperoleh deskripsi pekerjaan. Informasi ini sangat membantu dalam menentukan jumlah pegawai yang diperlukan, dan juga untuk menghasilkan spesifikasi pekerjaan. spesifikasi jabatan ini memberi gambaran tentang kualitas minimum pegawai yang dapat diterima dan yang perlu untuk melaksanakan pekerjaan sebagaimana mestinya (Hasibuan, 2017). Jadi, perencanaan sumber daya manusia merupakan cara untuk menetapkan tujuan dan pedoman pelaksanaan serta menjadi dasar kontrol/pengendalian pegawai.

\section{Pengadaan Pegawai}

Pengadaan pegawai merupakan kegiatan untuk memenuhi kebutuhan pegawai pada suatu lembaga, baik jumlah maupun kualitasnya. Untuk mendapatkan pegawai yang sesuai dengan kebutuhan, dilakukan kegiatan rekrutmen, yaitu usaha untuk mencari dan mendapatkan calon-calon pegawai yang memenuhi syarat sebanyak mungkin, untuk kemudian dipilih calon terbaik dan tercakap. Untuk kepentingan tersebut perlu dilakukan seleksi, melalui ujian lisan, tulisan, dan praktek. Namun adakalanya, pada suatu organisasi, pengadaan pegawai dapat didatangkan secara intern atau dari dalam organisasi saja, apakah melalui promosi atau mutasi. Hal tersebut dilakukan apabila formasi yang kosong sedikit, sementara pada bagian lain ada kelebihan pegawai atau memang sudah dipersiapkan. 
Pengadaan pegawai harus didasarkan pada prinsip apa baru siapa. Apa artinya kita harus terlebih dahulu menetapkan pekerjaan_pekerjaannya berdasarkan uraian pekerjaan. Siapa artinya kita baru mencari orang-orang yang tepat untuk menduduki jabatan tersebut berdasarkan spesifikasi pekerjaan. perekrutan calon pegawai hendaknya dilakukan dengan baik, agar pegawai yang diterima sesuai dengan kebutuhan pekerjaan yang akan dilakukan. Adapun proses atau langkah-langkah yang dilakukan dalam pengadaan pegawai yang meliputi:

1. Peramalan kebutuhan tenaga kerja dimaksudkan agar jumlah kebutuhan tenaga kerja masa kini dan masa depan sesuai dengan beban pekerjaan, kekosongan-kekosongan dapat dihindarkan dan semua pekerjaan dapat dikerjakan.

2. Penarikan (recruitment) adalah proses pencarian dan pemikatan tenaga kerja untuk mendapatkan sejumlah pelamar dari berbagai sumber, sesuai dengan kualifikasi yang dibutuhkan oleh suatu organisasi atau lembaga.

3. Seleksi (selection) adalah usaha pertama yang harus dilakukan organisasi/lembaga untuk memperoleh pegawai yang qualified dan kompeten yang akan menjabat serta mengerjakan semua pekerjaan pada organisasi/lembaga. Pelaksanaan seleksi harus dilakukan secara jujur, cermat, dan objektif supaya pegawai yang diterima benar-benar qualified untuk menjabat dan melaksanakan pekerjaan, sehingga pembinaan, pengembangan, dan pengaturan pegawai menjadi lebih mudah.

4. Penempatan, orientasi, dan induksi pegawai adalah tindak lanjut dari seleksi, yaitu menempatkan calon pegawai yang diterima (lulus seleksi) pada jabatan/pekerjaan yang membutuhkannya dan sekaligus mendelegasikan authority kepada orang tersebut. Penempatan pegawai yang tepat merupakan salah satu kunci untuk memperoleh prestasi kerja optimal dari setiap pegawai selain moral kerja, kreativitas, dan prakarsanya juga akan berkembang.

\section{Pembinaan dan Pengembangan Pegawai}

Organisasi senantiasa menginginkan agar personil-personilnya melaksanakan tugas secara optimal dan menyumbangkan segenap kemampuannya untuk kepentingan organisasi, serta bekerja lebih baik dari hari ke hari. Di samping itu, pegawai sebagai manusia juga membutuhkan peningkatan dan perbaikan pada dirinya termasuk dalam tugasnya. Sehubungan dengan itu, fungsi pembinaan dan pengembangan pegawai merupakan fungsi pengelolaan personil yang mutlak perlu, untuk memperbaiki, menjaga, dan meningkatkan kinerja pegawai. Kegiatan pembinaan dan pengembangan ini tidak hanya menyangkut aspek kemampuan, tetapi juga menyangkut karier pegawai (Hasibuan, 2017). 
Pengembangan pegawai dirasa semakin penting manfaatnya karena tuntutan pekerjaan atau jabatan, sebagai akibat kemajuan teknologi dan semakin ketatnya persaingan di antara organisasi/lembaga yang sejenis. Setiap personel organisasi/lembaga dituntut agar dapat bekerja efektif, efisien, kualitas dan kuantitas pekerjaannya baik sehingga daya saing organisasi/lembaga semakin besar. Pengembangan ini dilakukan untuk tujuan nonkarier maupun karier bagi para pegawai (baru atau lama) melalui latihan dan pendidikan (Oviyanti et al., 2011).12 Jadi pembinaan dan pengembangan pegawai (pendidikan dan latihan) perlu dilakukan setiap organisasi/lembaga karena akan memberikan manfaat bagi organisasi/lembaga, pegawai, dan masyarakat konsumen.

Metode pelatihan yang dapat dilaksanakan oleh sekolah untuk meningkatkan kualitas guru dan pegawai adalah: (a) Metode on the job training, guru dan pegawai baru mempelajari pekerjaannya dengan mengamati guru dan pegawai lainnya yang sedang melakukan pekerjaan. Guru dan pegawai senior memberikan pengetahuan dari pengalamannya; (b) Metode vestibule (balai), suatu ruangan terpisah yang disediakan untuk tempat pelatihan bagi guru dan pegawai baru, dilaksanakan dengan jumlah peserta yang banyak, dan diawasi oleh seorang instruktur; (c) Metode ruang kelas, merupakan metode pelatihan yang dilakukan di dalam kelas yaitu dengan format kegiatan kuliah, konferensi, studi kasus, bermain peran, dan pengajaran berprogram (programmed instruction).

Musyawarah Guru Mata Pelajaran (MGMP) merupakan wadah yang sesuai untuk melaksanakan pelatihan bagi guru. Forum MGMP memungkinkan guru untuk bermusyawarah memecahkan masalah yang dihadapi oleh guru baik dalam penanganan siswa maupun dalam kegiatan pembelajaran sehingga programprogram yang disusun sesuai dengan kurikulum dapat dilaksanakan dengan baik.

\section{Promosi dan Mutasi}

Promosi adalah perpindahan yang memperbesar authority dan responsibility pegawai ke jabatan yang lebih tinggi di dalam satu organisasi sehingga kewajiban, hak, status, dan penghasilannya semakin besar. Dengan adanya promosi berarti ada kepercayaan dan pengakuan mengenai kemampuan serta kecakapan pegawai bersangkutan untuk menduduki suatu jabatan yang lebih tinggi. Dengan begitu pegawai akan terdorong bekerja giat, bersemangat, berdisiplin, dan berprestasi kerja sehingga sasaran organisasi/lembaga secara optimal dapat dicapai. Promosi dilakukan bertitik tolak pada kepentingan organisasi. Guru yang berprestasi dapat dipromosikan menjadi kepala sekolah atau pengawas.

Mutasi adalah suatu perubahan posisi, jabatan, tempat, pekerjaan yang dilakukan baik secara horizontal maupun vertikal dalam suatu organisasi (Syukur, 2015). Mutasi 
dapat dipahami sebagai kegiatan memindahtugaskan pegawai dari pekerjaan yang diembannya saat ini ke pekerjaan lain yang ada di dalam organisasi (Priansa, 2014).

Mutasi selain memperhatikan dari kepentingan individu guru juga harus memperhatikan faktor lain seperti kemampuan penggajian lembaga yang akan dituju, penyebaran guru, dan kebutuhan akan guru. Memperhatikan faktor tersebut diharapkan tidak terjadinya kesenjangan jumlah guru antara sekolah satu dengan sekolah yang lain. Sekolah tertentu memiliki guru yang berlebihan sedangkan sekolah lain kekurangan jumlah guru, maka dengan mutasi yang efektif diharapkan dapat menyelesaikan permasalahan tersebut.

\section{Pemberhentian Pegawai}

Pemberhentian adalah pemutusan hubungan kerja seseorang pegawai dengan suatu organisasi/lembaga. Dengan pemberhentian, berarti berakhirnya keterikatan kerja pegawai terhadap organisasi. Pemberhentian pegawai merupakan fungsi personalia yang menyebabkan terlepasnya pihak organisasi dan personil dari hak dan kewajiban sebagai lembaga tempat kerja dan sebagai pegawai. Dalam kaitannya dengan tenaga kependidikan di sekolah, khususnya Pegawai Negeri Sipil sebab-sebab pemberhentian pegawai ini dapat dikelompokkan ke dalam tiga jenis yaitu: 1) Pemberhentian atas permohonan sendiri; 2) Pemberhentian oleh dinas dan pemerintah; 3) Pemberhentian sebab lain-lainnya.

Pemberhentian atas permohonan pegawai sendiri, misalnya karena pindah lapangan pekerjaan yang bertujuan memperbaiki nasib. Pemberhentian oleh dinas atau pemerintah bisa dilakukan dengan beberapa alasan berikut: 1) Pegawai yang bersangkutan tidak cakap dan tidak memiliki kemampuan untuk melaksanakan tugastugasnya dengan baik; 2) Perampingan atau penyederhanaan organisasi; 3) Peremajaan, biasanya pegawai yang telah berusia 55 tahun dan berhak pensiun harus diberhentikan dalam jangka waktu satu tahun; 4) Tidak sehat rohani dan jasmani sehingga tidak dapat melaksanakan tugasnya dengan baik; 5) Melakukan pelanggaran tindak pidana sehingga dihukum penjara atau kurungan; 6) Melanggar sumpah atau janji PNS. Sementara pemberhentian karena alasan lain penyebabnya pegawai yang bersangkutan meninggal dunia, hilang, habis menjalani cuti di luar tanggungan negara dan tidak melaporkan diri kepada yang berwenang, serta telah mencapai batas usia pensiun.

\section{Kompensasi}

Kompensasi adalah balas jasa yang diberikan organisasi kepada pegawai, yang dapat dinilai dengan uang dan mempunyai kecenderungan yang diberikan secara tetap. Pemberian kompensasi selain dalam bentuk gaji dapat juga berupa tunjangan, fasilitas perumahan, kendaraan, dan lain-lain. Pemberian kompensasi ini tidak lagi 
dipandang sebagai pemuas kebutuhan material tetapi sudah dikaitkan dengan harkat dan martabat manusia. Kompensasi sebagai bentuk pembayaran atau imbalan yang diberikan kepada pegawai dari pelaksanaan pekerjaannya. Sekolah perlu memperhatikan kompensasi sebagai hadiah kepada guru dan pegawai yang aktif terlibat dalam pencapaian tujuan sekolah. Kepala sekolah memperhatikan kesejahteraan guru agar dapat meminimalkan ketimpangan faktor ekonomi sesama guru. Terpenuhinya kebutuhan guru diharapkan guru konsisten dan aktif dengan tugas utamanya yaitu melaksanakan kegiatan pembelajaran dengan peserta didik. Sehingga kasus guru yang meninggalkan tugas utamanya sebagai pendidik karena bekerja bidang lain dapat diatasi.

\section{Penilaian Pegawai}

Prestasi kerja merupakan hasil kerja secara kualitas dan kuantitas yang dicapai oleh seseorang pegawai dalam melaksanakan tugasnya sesuai dengan tanggung jawab yang diberikan kepadanya (Mulyasa, 2012). Dalam bidang pendidik dan tenaga kependidikan, satuan pendidikan sekolah melaksanakan program dengan standar manajemen sebagai berikut:

1. Sekolah/madrasah menyusun program pendayagunaan pendidik dan tenaga kependidikan.

2. Program pendayagunaan pendidik dan tenaga kependidikan: a) Disusun dengan memperhatikan standar pendidik dan tenaga kependidikan; b) Dikembangkan sesuai dengan kondisi sekolah/madrasah termasuk pembagian tugas, mengatasi bila terjadi kekurangan tenaga, menentukan sistem penghargaan, dan pengembangan profesi bagi setiap pendidik dan tenaga kependidikan serta menerapkannya secara profesional, adil, dan terbuka.

3. Pengangkatan pendidik dan tenaga kependidikan tambahan dilaksanakan berdasarkan ketentuan yang ditetapkan oleh penyelenggaraan sekolah/madrasah.

4. Sekolah/madrasah perlu mendukung upaya: a) Promosi pendidik dan tenaga kependidikan berdasarkan asas kemanfaatan, kepatutan, dan profesionalisme; b) Pengembangan pendidik dan tenaga kependidikan yang di identifikasi secara sistematis sesuai dengan aspirasi individu, kebutuhan kurikulum dan sekolah/madrasah; c) Penempatan tenaga kependidikan disesuaikan dengan kebutuhan baik jumlah maupun kualifikasinya dengan menetapkan prioritas; d) Mutasi tenaga kependidikan dari satu posisi ke posisi lain didasarkan pada analisis jabatan dengan diikuti orientasi tugas oleh pimpinan tertinggi sekolah/madrasah yang dilakukan setelah empat tahun, tetapi bisa diperpanjang berdasarkan alasan yang dapat dipertanggungjawabkan, sedangkan untuk tenaga kependidikan tambahan tidak ada mutasi. 
5. Sekolah/Madrasah:

a. Kepala sekolah/madrasah melaksanakan tugas dan tanggung jawabnya sebagai pimpinan pengelolaan sekolah/madrasah;

b. Wakil kepala SMP/MTS melaksanakan tugas dan tanggung jawabnya sebagai pembantu kepala sekolah/madrasah;

c. Wakil kepala SMA/SMK, MA/MAK bidang kurikulum melaksanakan tugas dan tanggung jawabnya sebagai pembantu kepala sekolah/madrasah dalam mengelola bidang kurikulum;

d. Wakil kepala SMA/SMK, MA/MAK bidang sarana prasarana melaksanakan tugas dan tanggung jawabnya sebagai pembantu kepala sekolah/madrasah dalam mengelola sarana prasarana;

e. Wakil kepala SMA/SMK, MA/MAK bidang kesiswaan melaksanakan tugas dan tanggung jawabnya sebagai pembantu kepala sekolah/madrasah dalam mengelola peserta didik;

f. Wakil kepala SMK bidang hubungan industri melaksanakan tugas dan tanggung jawabnya sebagai pembantu kepala sekolah/ madrasah dalam mengelola kemitraan dengan dunia usaha dan dunia industry;

g. Guru melaksanakan tugas dan tanggung jawabnya sebagai agen pembelajaran yang memotivasi, memfasilitasi, mendidik, membimbing, dan melatih peserta didik sehingga menjadi manusia berkualitas dan mampu mengaktualisasikan potensi kemanusiaannya secara optimum;

h. Konselor melaksanakan tugas dan tanggung jawabnya dalam memberikan layanan bimbingan dan konseling kepada peserta didik;

i. Pelatih/instruktur melaksanakan tugas dan tanggung jawabnya memberikan pelatihan teknis kepada peserta didik pada kegiatan pelatihan;

j. Tenaga perpustakaan melaksanakan tugas dan tanggung jawabnya melaksanakan pengelolaan sumber belajar di perpustakaan;

k. Tenaga laboratorium melaksanakan tugas dan tanggung jawabnya membantu guru mengelola kegiatan pratikum di laboratorium;

l. Teknisi sumber belajar melaksanakan tugas dan tanggung jawabnya mempersiapkan, merawat, memperbaiki sarana dan prasarana pembelajaran;

m. Tenaga administrasi melaksanakan tugas dan tanggung jawabnya dalam menyelenggarakan pelayanan administratif;

n. Tenaga kebersihan melaksanakan tugas dan tanggung jawabnya dalam memberikan layanan kebersihan lingkungan.

Dengan ditetapkannya standar pelaksanaan program manajemen pendidik dan kependidikan, sekolah memiliki pedoman dalam menjalankan dan mengembangkan program-program yang telah disusun oleh pihak sekolah. Dengan hal ini tugas kepala 
sekolah sebagai pengelola sumber daya manusia (SDM) bukanlah pekerjaan yang mudah karena kepala sekolah dituntut untuk mengerjakan instrumen pengelolaan tenaga kependidikan untuk membantu kelancaran MBS di sekolah yang dipimpinnya.

\section{Tujuan Manajemen Sumber Daya Manusia}

Setiap organisasi menetapkan tujuan-tujuan tertentu yang ingin mereka capai dalam mengatur sumber dayanya termasuk sumber daya manusia. Tujuan manajemen sumber daya manusia secara tepat sangatlah sulit untuk dirumuskan karena sifatnya bervariasi dan tergantung pada penahapan perkembangan yang terjadi pada masingmasing organisasi (Sutrisno, 2014). Untuk mencapai kebermaknaan sumber daya manusia yang optimal, diperlukan manajemen dengan tujuan yang jelas. Tujuan manajemen menurut Ulfatin \& Triwiyanto $(2016$, h. 11) dapat dilihat dari tingkat yang paling rendah, yaitu tingkat personal (personal objective), naik ke tingkat yang lebih tinggi, yaitu tujuan fungsional (function objective), dilanjutkan ke tujuan organisasional (organizational objective), dan puncaknya untuk tujuan layanan masyarakat secara nasional dan internasional (society objective).

\section{Tujuan Personal (Personal Objective)}

Tujuan personal yaitu membantu sumber daya manusia untuk mencapai tujuan diri individunya. Tujuan individual ini berentang dari yang sangat teknis sampai dengan yang aspirasi, dan dari tujuan jangka pendek sampai dengan jangka panjang. Tujuan yang bersifat teknis, setiap individu tercermin dari kegiatan riil dan kontribusi dirinya dalam organisasi, sedangkan tujuan aspirasi tercermin pada motivasi dan kepuasannya dalam organisasi. Tujuan jangka pendek individu umumnya untuk mencapai pemenuhan kebutuhan dasar seperti makan, minum, dan sandang, sampai dengan kebutuhan tingkat tinggi yaitu aktualisasi diri (lihat teori Maslow). Sedangkan kebutuhan jangka panjang merupakan kebutuhan rohani untuk mencapai tujuan di akhirat nanti. Kebutuhan jangka panjang ini tercermin dari keyakinannya bahwa pencapaian tujuan duniawi (terutama bekerja) merupakan alat untuk memenuhi kebutuhan rohani di akhirat nanti.

\section{Tujuan Fungsional (Functional Objective)}

Tujuan fungsional manajemen sumber daya manusia adalah tujuan yang memelihara kontribusi bagian-bagian dalam organisasi agar sumber daya manusia pada bagian-bagian itu dapat menjalankan tugas secara optimal. Setiap sumber daya manusia akan memiliki makna fungsional jika manajemennya mampu memenuhi tujuan permintaan organisasi. Dengan demikian manajemen bertugas untuk mengoptimalkan agar setiap sumber daya manusia dapat berkontribusi pada bagian tugas dan fungsi yang dijalankan. Tujuan fungsional manajemen sumber daya manusia 
adalah menjaga agar guru tidak terlambat di kelas dan guru dapat membuat persiapan secara baik. Dengan kata lain, tujuan fungsional adalah memelihara dan memfasilitasi agar guru dapat menjalankan tugasnya secara optimal sesuai tugas dan fungsinya.

\section{Tujuan Organisasional (Organizational Objective)}

Tujuan organisasional manajemen sumber daya manusia adalah tujuan yang terkait dengan keefektifan organisasi. Tujuan organisasional ini tercermin dari pencapaian kinerja dan produktivitas organisasi. Jika organisasi itu sekolah, tujuan organisasionalnya adalah tingkat dan kualitas lulusan sekolah. Tingkat dan kualitas lulusan sekolah sangat tergantung pada kinerja dan produktivitas pada pendidik dan tenaga kependidikan yang ada di sekolah, di samping juga tergantung kepada sumbersumber yang lain. Sebagai contoh tujuan organisasional para pendidik dan tenaga kependidikan adalah melayani dan mengoptimalkan bagian-bagian dalam organisasi (misalnya manajemen peserta didik) untuk mencapai tujuan sekolah.

\section{Tujuan Masyarakat (Society Objective)}

Tujuan masyarakat adalah untuk memenuhi kebutuhan dan tantangan yang timbul di masyarakat, sehingga organisasi diharapkan dapat memberi manfaat atau keuntungan bagi masyarakat. Pencapaian tujuan masyarakat merupakan dampak (outcomes) yang ditimbulkan dari pencapaian tujuan sebelumnya, yaitu tujuan organisasional. Pencapaian tujuan masyarakat pendidikan tercermin dari keberhasilan generasi yang dihasilkan oleh sekolah sebagai warga masyarakat yang jauh lebih berkualitas dari masyarakat pada generasi sebelumnya.

\section{PENUTUP}

Manajemen sumber daya manusia merupakan salah satu bidang dari manajemen umum yang meliputi segi-segi perencanaan, pengorganisasian, pelaksanaan, dan pengendalian. Sumber daya manusia dianggap semakin penting karena dalam pencapaian tujuan organisasi, maka berbagai pengalaman dan hasil penelitian dalam bidang sumber daya manusia dikumpulkan secara sistematis dengan apa yang disebut dengan manajemen sumber daya manusia. Istilah management mempunyai arti sebagai kumpulan pengetahuan tentang bagaimana seharusnya me-manage (mengelola) sumber daya manusia. Untuk mencapai kebermaknaan sumber daya manusia yang optimal, maka diperlukan manajemen dengan tujuan yang jelas.

Tujuan manajemen dapat dilihat dari tingkat yang paling rendah, yaitu tingkat personal (personal objective), naik ke tingkat yang lebih tinggi, yaitu tujuan fungsional (function objective), dilanjutkan ke tujuan organisasional (organizational objective), dan puncaknya untuk tujuan layanan masyarakat secara 
nasional dan internasional (society objective). Manajemen sumber daya manusia menganggap bahwa karyawan adalah kekayaan utama yang dimiliki organisasi yang harus dikelola dengan baik. Oleh karena itu, manajemen sumber daya manusia sifatnya lebih strategis bagi organisasi dalam mencapai tujuan-tujuan yang telah ditetapkan. Peran manajemen sumber daya manusia sebagai faktor sentral dalam organisasi dapat dikelompokkan menjadi beberapa peran, di antaranya peran administrasi manajemen sumber daya manusia, peran operasional manajemen sumber daya manusia, dan peran strategis manajemen sumber daya manusia.

\section{DAFTAR PUSTAKA}

Akilah, F., \& Rahman, D. (2020). TELAAH FUNGSIONAL KONSEPSI INSENTIF. 10(2), 187-196.

Amirullah, \& Budiyono, H. (2004). Pengantar Manajemen. Malang: Graha Ilmu.

Arsyad, A. (2011). Pokok-Pokok Manajemen: Pengetahuan Praktis Bagi Pimpinan dan Eksekutif. Yogyakarta: Pustaka Pelajar.

Hasibuan, M. S. P. (2017). Manajemen Sumber Daya Manusia. (Jakarta: Bumi Aksara.

Herfan, D. (1999). Peran SDM dalam Penerapan. Jakarta: Grasindo.

Mulyasa, E. (2012). Manajemen Berbasis Sekolah. Bandung: Remaja Rosdakarya.

Oviyanti, F. (2011). Manajemen Berbasis Sekolah (MBS). Palembang: IAIN Raden Fatah Palembang.

Priansa, D. J. (2014). Perencanaan dan Pengembangan SDM. Bandung: Alfabeta.

Sutrisno, E. (2014). Manajemen Sumber Daya Manusia. Jakarta: Kencana.

Syukur, F. (2015). Manajemen Sumber Daya Manusia Pendidikan. Semarang: Program Pascasarjana IAIN Walisongo Semarang.

Trisnawati, E. (2005). Pengantar Manajemen. Jakarta: Kencana.

Ulfatin, N., \& Triwiyanto, T. (2016). Manajemen Sumber Daya Manusia Bidang Pendidikan. Jakarta: RajaGrafindo Persada.

Yunanik. (2013). Implementasi Analisis Jabatan dalam Rangka Menyiapkan Organisasi Akamigas Menuju. Jurnal, 22(2). 